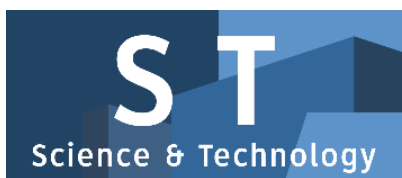

PAPER - OPEN ACCESS

\title{
Optimisasi Program Linear Integer Murni Dengan Metode Branch And Bound
}
Author
: Tondi Marulizar
DOI
: $10.32734 /$ st.v1i2.295
Electronic ISSN
: 2654-7082
Print ISSN
:2654-7074

Volume 1 Issue 2 - 2018 TALENTA Conference Series: Science \& Technology (ST)

\section{(C) $(1)$}

This work is licensed under a Creative Commons Attribution-NoDerivatives 4.0 International License.

Published under licence by TALENTA Publisher, Universitas Sumatera Utara
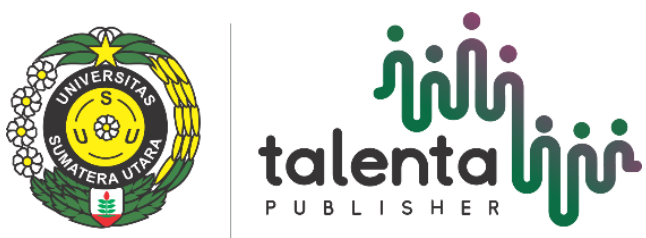


\title{
Optimisasi Program Linear Integer Murni Dengan Metode Branch And Bound
}

\author{
Tondi Marulizar ${ }^{a *}$, Ujian Sinulingga $^{\mathrm{b}}$, Esther Nababan ${ }^{\mathrm{c}}$ \\ ${ }^{a}$ Departemen Matematika FMIPA,Universitas Sumatera Utara, Indonesia \\ esther@usu.ac.id; marulizar@gmail.com; ujian.sinulingga@usu.ac.id
}

\begin{abstract}
Abstrak
Program Linier Integer Murni merupakan optimisasi kombinatorial yang tidak mudah untuk diselesaikan secara efisien. Metode yang sering digunakan untuk menyelesaikan Program Linier Integer Murni diantaranya adalah metode merative, yang merupakan salah satunya metode Branch and Bound. Metode ini menggunakan hasil dari metode simpleks yang belum bernilai integer sehingga dilakukan pencabangan dan batasan terhadap variabel $x_{j}$ yang bernilai pecahan terbesar. Metode Branch and Bound dapat menyelesaikan masalah optimisasi suatu produk, tetapi membutuhkan waktu yang lebih lama dalam proses perhitungannya dikarenakan dalam setiap tahap perhitungan harus dicari nilai dari batas atas dan batas bawah yang ditentuan berdasarkan suatubatasandankriteria tertentu.
\end{abstract}

Kata kunci : Pure integer; integer programming; metode branch and bound;

\section{Pendahuluan}

Salah satu keputusan manajerial yang sangat penting adalah penyaluran sumber daya yang sangat langka. Sumber daya yang dimaksud dapat berupa uang, bahan baku, tenaga kerja, peralatan dan mesin, ruang, atau waktu. Model analisa yang terbaik untuk menyelesaikan persoalan alokasi sumber daya ialah model program linear (P. Siagian, 1987).

Program linear berperan sebagai piranti untuk membantu dalam pengambilan keputusan manajemen dengan cara mengidentifikasi kombinasi sumber daya yang tersedia sehingga tujuan yang diinginkan dapat tercapai secara optimal (Parlin Sitorus, 1997).bProgram integeradalah program linear (linear programming) di mana variabel-variabelnya bertipe integerb(bulat). Program integer digunakan untuk memodelkan permasalahan yang variabel-variabelnya tidak mungkin berupa bilangan yang tidak bulat(bilangan riil), seperti variabel yang mempresentasikan jumlah orang atau benda, karena jumlah orang atau benda pasti bulat dan tidak mungkin berupa pecahan. Program integer juga biasanya lebih dipilih untuk memodelkan suatu permasalahan karena program linear dengan variabel berupa bilangan riil kurang baik dimodelkan dalam permasalahan yang menuntut solusi berupa bilangan integer, misalnya variabelvariabel keputusannya jumlah cabang perusahaan di daerah berbeda di suatu negara. Solusi pecahan tentu tidak dapat diterima dalam keputusan perusahaan.

Pada permasalahan maksimum atau minimum, setiap model variabel dapat bernilai riil. Dalam beberapa kondisi tertentu sering mendekati atau mempunyai penyelesaian pecahan. Sebagai contoh, suatu solusi yang memerlukan 2,29 kapal selam dalam suatu sistem pertahanan adalah tidak mempunyai makna praktis. Dalam kasus ini, 2 atau 3 kapal selam harus disediakan (bukan 2,29 kapal selam). 
Walaupun demikian masih banyak masalah lain dalam kasus optimisasi, sangat sulit membulatkan penyelesaian tanpa melanggar beberapa dari kendala (constraint). Sering terjadi jika memprediksi variabel yang tepat, perlu mengganti nilai beberapa variabel untuk memenuhi semua kendala. Akibatnya jika membulat penyelesaian bisa saja memberikan suatu nilai fungsi objektif yang sangat jauh dari nilai optimal awal. Semua kesulitan-kesulitan ini dapat dihindari jika masalah optimisasi (maksimum/minumum) dimodelkan dan diselesaikan sebagai masalah program linear.

Pada problema optimisasi dengan kendala linear dan terdapat beberapa variabel yang dibatasi bernilai integer, maka masalah optimisasi ini dinyatakan sebagai masalah pure integer linear programming.

Banyak metode yang dapat digunakan untuk menyelesaikan permasalahan pure integer linear programming yang tiap-tiap metode mempunyai kelebihan dan kelemahan. Berdasarkan penjelasan di atas maka penulis menggunakan metode Branch and Bound dalam menyelesaikan masalah pure integer linear programming.

Adapun metode yang digunakan dalam penyelesaian masalah pure integer linear programming adalah metode branch and bound. Metode ini pertama kali dikembangkan oleh A.H Land dan A. G. Doig dan kemudian diperbaiki oleh R. J. Dakin. Konsep dasar dari metode branch and bound adalah terhadap tiap-tiap nilai $x_{j}$, diberikan $\left[x_{j}\right] \leq x_{j} \leq$ $\left[x_{j}\right]+1$ dimana $\left[x_{j}\right]$ adalah bilangan bulat terdekat yang lebih kecil dari $x_{j}$.

\section{Program Integer}

Program integer adalah program linear (linear programming) di mana variabel-variabelnya bertipe integerb(bulat). Program integer digunakan untuk memodelkan permasalahan yang variabel-variabelnya tidak mungkin berupa bilangan yang tidak bulat(bilangan riil), seperti variabel yang mempresentasikan jumlah orang atau benda, karena jumlah orang atau benda pasti bulat dan tidak mungkin berupa pecahan. Program integer juga biasanya lebih dipilih untuk memodelkan suatu permasalahan karena program linear dengan variabel berupa bilangan riil kurang baik dimodelkan dalam permasalahan yang menuntut solusi berupa bilangan integer, misalnya variabel-variabel keputusannya jumlah cabang perusahaan di daerah berbeda di suatu negara. Solusi pecahan tentu tidak dapat diterima dalam keputusan perusahaan.

Pada masalah program integer untuk pola memaksimumkan, nilai tujuan dari program integer tidak akan pernah melebihi nilai tujuan dari program linear, apabila melebihi maka tidak diperoleh penyelesaian layak atau infeasible (Wahyujati, Ajie. 2009).Program integer merupakan bagian dari program matematika (mathematical programming). Adapun permasalahan program matematika secara umum dapat dinyatakan sebagai :

Optimisasikan $Z(x), x \in S \subseteq R^{n}$ dengan $R^{n}$ adalah himpunan semua vektor riil $n$ komponen dan $z$ suatu fungsi riil yang didefinisikan dalam $S$. Himpunan $S$ dinamakan himpunan kendala (constraint) dan $z$ disebut fungsi objektif (objective function).

Permasalahan pada program matematika bertujuan untuk mencari solusi optimal. Untuk mencari solusi optimal tersebut, harus diketahui apa yang dimaksud dengan solusi layak (feasible solution). Setiap, $x \in S$ pada persamaan di atas disebut sebagai solusi layak, sedangkan untuk $x^{0} \in S$ yang sudah memenuhi $z(x)<z\left(x^{0}\right)<\infty, \forall x \in$ $S$ dinyatakan sebagai solusi optimal (optimal solution) dari persamaan di atas yang memaksimumkan $Z(x)$. Masalah program matematika dengan $S \subseteq Z^{n} \subseteq R^{n}$, dan $Z^{n}$ himpunan semua vektor bilangan bulat $n$ komponen, disebut masalah integer programming.

\section{Karakteristik-karakteristik dalam Program Linear}

Dalam membangun model dari formulasi akan digunakan karakteristik-karakteristik yang biasa digunakan dalam persoalan program linear yaitu:

\section{a. Variabel keputusan}

Variabel keputusan adalah variabel yang menguraikan secara lengkap keputusan-keputusan yang akan dibuat.

\section{b. Fungsi tujuan}

Fungsi tujuan merupakan fungsi dari variabel keputusan yang akan dimaksimumkan (pendapatan atau keuntungan) atau diminumkan (biaya atau ongkos). 
c. Pembatas

Pembatas merupakan kendala yang dihadapi sehingga kita tidak bisa menentukan harga-harga variabel keputusan secara sembarang.

d. Pembatas tanda

Pembatas tanda adalah yang menjelaskan apakah variabel keputusannya diasumsikan hanya berharga negatif atau variabel keputusannya boleh berharga positif.

Sifat Umum Program Integer

Semua persoalan program integer mempunyai empat sifat umum yaitu, sebagai berikut (Susanta, B. 1994):

1. Fungsi Tujuan (objective function)

2. Persoalan program integer bertujuan untuk memaksimumkan atau meminimumkan pada umumnya berupa laba atau biaya sebagai hasil yang optimal.

3. Adanya kendala atau batasan (constraint) yang membatasi tingkat sampai di mana sasaran dapat dicapai. Oleh karena itu, untuk memaksimumkan atau meminimumkan suatu kuantitas fungsi tujuan bergantung kepada sumber daya yang jumlahnya terbatas.

4. Harus ada beberapa alternatif solusi layak yang dapat dipilih.

5. Tujuan dan batasan dalam permasalahan program integer harus dinyatakan dalam hubungan dengan pertidaksamaan atau persamaan linear.

Pure integer linear programming adalah masalah integer programming dimana semua variabel keputusannya terbatas hanya untuk bilangan bulat.

Bentuk umum dari pure integer programming adalah:

Optimisasikan $\quad: \quad Z=\sum_{j=1}^{n} c_{j} x_{j}$

Dengan kendala :

$$
\begin{aligned}
& \sum_{j=1}^{n} a_{i j} x_{j}(\leq, \geq,=) b_{i} \\
& x_{j} \geq 0, \text { daninteger } \\
& i=1,2,3, \cdots, m \\
& j=1,2,3, \cdots, n
\end{aligned}
$$

Dengan $a_{i j}, b_{i}$, danc $_{j}$ adalah konstanta.

Mixed integer linear programming adalah masalah integer programming dengan beberapa variabel keputusannya dibatasi sebagai bilangan bulat, dan sementara yang lain tidak.

Bentuk umum dari mixed integer programming adalah:

Optimisasikan

Dengan kendala

$$
: Z=\sum_{j=1}^{n} c_{j} x_{j}+\sum_{k=1}^{p} d_{k} y_{k}
$$

$$
\sum_{j=1}^{n} a_{i j} x_{j}+\sum_{k=1}^{p} g_{i k} y_{k}(\leq, \geq,=) b_{i}
$$

$$
\begin{gathered}
i=1,2,3, \cdots, m \\
x_{j} \geq 0, \quad \text { dan integer } \\
j=1,2,3, \cdots, n \\
y_{k} \geq 0, k=1,2,3, \cdots, p
\end{gathered}
$$


Zero integer linear programming adalah masalah integer programming dimana variabel keputusannya hanya bernilai nol atau satu.

Bentuk umum dari mixed integer programming adalah:

Optimisasikan :

$$
Z=\sum_{j=1}^{n} c_{j} x_{j}
$$

$$
\begin{aligned}
& \begin{array}{l}
\text { Dengan kendala: } \\
\sum_{j=1}^{n} a_{i j} x_{j} \leq b_{i} \\
i=1,2,3, \cdots, m \\
x_{j} \geq 0, \quad j=1,2,3, \cdots, n
\end{array}
\end{aligned}
$$

\section{Metode Branch and Bound}

Branch and Bound pertama kali digunakan oleh A. Land dan G. Doig untuk menyelesaikan persoalan program bilangan cacah murni dan campuran. Kemudian pada tahun 1965, E. Balas mengembangkan algoritma tambahan untuk menyelesaikan integer linear programming dengan bilangan biner murni (pure binary) atau variabel nol-satu. Perhitungan algoritma tambahan ini sangat sederhana (umumnya, penambahan dan pengurangan) yang dapat menghasilkan solusi pemecahan untuk problema integer linear programming. Akan tetapi, algoritma tambahan ini gagal untuk menghasilkan keuntungan penghitungan yang diharapkan. Selain itu, algoritma tersebut yang pada awalnya tampak tidak berhubungan dengan metode branch and bound, tetapi bukan merupakan problema khusus algoritma umum dari Land dan Doig. (Hamdy A. Taha, 2007)

\section{Algoritma Metode Branch and Bound}

Berikut ini adalah langlah-langkah penyelesaian suatu masalah pure integer linear programming dengan metode branch and bound:

1. Formulasikan permasalahan dalam model matematika, tentukan fungsi tujuan dan kendala.

2. Ubah model matematika tersebut ke dalam bentuk standar.

3. Selesaikan model yang baru dengan menggunakan metode simpleks.

4. Jika hasil yang ditemukan sudah berupa bilangan bulat, maka solusi optimum sudah didapatkan. Akan tetapi, apabila hasil yang didapat belum berupa bilangan bulat, maka akan dilakukan pencabangan.

5. Lakukan metode simpleks untuk mengoperasikan linear programming dengan penambahan kendala yang baru dan tetapkan batas untuk setiap iterasi yang dilakukan.

6. Langkah tersebut dilakukan berulang sampai ditemukan hasil yang bulat. 


\section{Metodologi}

Permasalahan dibagi menjadi submasalah-submasalah yang mungkin mengarah ke solusi. Inilah yang disebut branching, mengingat prosedur ini akan dilakukan berulang-ulang secara rekursif untuk setiap submasalah dan setiap submasalah yang dihasilkan akan membentuk sebuah pohon yang disebut sebagai pohon pencarian (search tree) di mana simpul simpulnya membangun submasalah-submasalah. Selain branching, algoritma ini juga melakukan apa yang disebut dengan bounding yang merupakan cara cepat untuk mencari batas atas dan batas bawah untuk solusi optimal pada submasalah yang mengarah ke solusi. Adapun diagram alir penerapan metode branch and bound dalam menyelesaikan Pure Integer Linear Programming dengan optimisasi maksimum disajikan dalam gambar 1 sebagai berikut,

\section{Pembahasan}

Berikutadalahcontoh penyelesaian masalahPure Integer Linear Programming dengan metodeBranch and Bound(Sumber :Sinurat, R. R. 2008)

Maksimumkan :

$$
Z=4 x_{1}-2 x_{2}+7 x_{3}-x_{4}
$$

Kendala

$x_{1}+5 x_{3} \leq 10$

$x_{1}+x_{2}-x_{3} \leq 1$

$6 x_{1}-5 x_{2} \leq 0$

$-x_{1}+2 x_{3}-2 x_{4} \leq 3$

$x_{j} \geq 0$ untukj $=1,2,3,4$

$x_{j}$ bulatuntukj $=1,2,3,4$

Masalah tersebut ditransformasikan ke dalam bentuk standarnya menjadi:

Maksimumkan $\quad Z=4 x_{1}-2 x_{2}+7 x_{3}-x_{4}$

Kendala :

$$
\begin{aligned}
& x_{1}+5 x_{3}+x_{5} \leq 10 \\
& x_{1}+x_{2}-x_{3}+x_{6} \leq 1 \\
& 6 x_{1}-5 x_{2}+x_{7} \leq 0 \\
& -x_{1}+2 x_{3}-2 x_{4}+x_{8} \leq 3 \\
& x_{j} \geq 0 \text { untukj }=1,2,3,4,5,6,7,8 \\
& x_{j} \text { bulatuntukj }=1,2,3,4
\end{aligned}
$$


Langkah awal: setelah menetapkan $Z^{*}=-\infty$ dibentuk program linear relaksasi dari masalah ini dengan menghilangkan gugus kendala $x_{j}$ adalah bilangan bulat untuk $j=1,2,3,4$. Dengan menggunakan metode simpleks program linear relaksasi diperoleh adalah $x_{1}=\frac{5}{4}, x_{2}=\frac{3}{2}, x_{3}=\frac{7}{4}, x_{4}=0$ denganZ $=14 \frac{1}{4}$

Karena persamaan linear relaksasi ini mempunyai penyelesaian layak dan penyelesaian optimal ini mempunyai nilai yang bukan bilangan bulat untuk varibel-variabel yang dibatasi bulat, maka pada masalah akan dilakukan pencabangan (branch) pada salah satu variabel yang belum bulat, misalkan $x_{1}$ dicabangkan, sehingga masalah keseluruhan tidak dihentikan sehingga algoritma tersebut dijalankan. Pencabangan dan iterasi berhenti apabila seluruh variabel telah bilangan bulat, sepertipada diagram berikut :

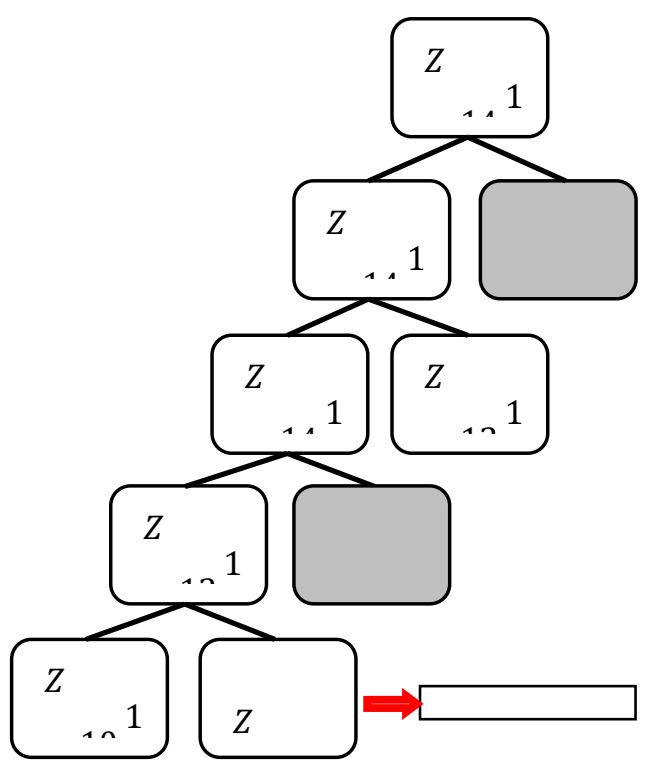

Gambar 1. Diagram Branch and Bound

Operasi pencabangan tersebut akan menelurusi semua solusi bilangan bulat feasible yang mungkin, sedangkan konsep pembatasan dipakai untuk mempersempit daerah yang layak penelurusan sehingga beberapa solusi bilangan bulat feasible yang tidak potensial dapat dibuang.Pemilihan batas yang baik pada tahap awal perhitungan pada metode branch and bound tidak bisa ditentukan. Hal ini tergantung pada urutan sub-submasalah tersebut dibangun dan ditelusuri. Hal ini berkaitan dengan pemilihan urutan variabel yang dipakai untuk mempartisi masalah menjadi subsubmasalah.

Pemilihan yang berbeda akan menghasilkan urutan proses yang berbeda dan akibatnya jumlah iterasi untuk mendapatkan solusi bilangan bulat yang optimum juga bisa berbeda. Oleh Karena itu metode branch and bound cukup memakan banyak waktu dan memerlukan banyak perhitungan. Solusi optimal diperoleh bila seluruh variebel keputusan telah memiliki nilai bilangan bulat (integer).

\section{Kesimpulan}

Metode Branch and Bound dapat digunakan untuk menentukan penyelesaian solusi optimal dalam masalah perencanaan linear pure integer linear programming. Algoritma Branch and Bound cukup efektif digunakan pada permasalahan pure integer linear programming dengan variabel keputusan yang berjumlah sedikit. Akan tetapi dalam menyelesaikan permasalahan ini, algoritma branch and bound mempunyai keterbatasan yaitu pemilihan batas yang 
baik pada tahap awal perhitungan pada metode branch and bound tidak dapat ditentukan, dan jumlah iterasi sangat bergantung pada pemilihan titik awal.Dengandemikian dibutuhkan waktu yang lama untuk menemukan solusi optimal.

\section{Daftar Pustaka}

[1] Aminudin. 2005. Prinsip-Prinsip Riset Operasi. Jakarta: PT Gelora Aksara Pratama.

[2] Bangun, E. 2004. Kajian Strategis untuk Menyelesaikan Integer Program dengan Metode Branch and Bound.[Tesis]. Medan: Universitas Sumatera Utara.

[3] Bu'ulölö, F. 2016. Opeasi Riset: Program Linear. Medan: Universitas Sumatera Utara Press.

[4] Enty N. H. 2010. Aplikasi Algoritma Branch and Bound untuk Menyelesaikan Integer Programming. Dinamika Teknik. Vol. IV No. 1 Januari 2010 Hal 13-23.

[5] Mulyadi, A. 2008. Penyelesaian Mixed Integer Programming dengan Menggunakan Metode Branch and Bound. [Tesis]. Padang: Universitas Andalas.

[6] Nasendi B. D. 1985. Program Linear dan Variasinya. Jakarta: PT Gramedia Pustaka Utama

[7] Sinurat, R. R. 2008. Studi Penyelesaian Problema Mixed Integer Programming dengan Menggunakan Metode Branch and Cut. [Skripsi]. Medan: Universitas Sumatera Utara.

[8] Umami, A., E. NababandanSawaludin, 2015., KKT Conditions and Branch and

[9] Bound Methods on Pure Integer Nonlinear Programming, International

[10] Journal of Mathematical Analysis and Applications 2015; 2(4): 62-67 